\title{
Relasi kebudayaan Terhadap ilmu pendidikan, Iman Karakter.di tengah tengah dunia digital
}

Oleh:

\section{Wawan Parebong}

\begin{abstract}
Abstrak :
Perkembangan pendidikan mulai Meluas tatapi tidak semua pendidikan meluas ke seluru kehidupan Manusia Pada dasarnya pendidikan masa kini hanyalah sebuah kebudayaan yang seakan-akan tidak penting lagi.terkadang manusia hanya memandang pendidikan secara fromalitas saja misalkan menempuh pemdidikan di sekolah.seolah olah kemudian menekan para penganut pendidikan mjsalkan siswa dan mahasiswa.tanmpa di sadari pendidikan bukan hanya di capai di ruang belajr/sekolah tetapi bisa juga dari luar.terkadang jika lihat dunia sekarang pendidikan lebih banyak di temukan di dunia maya/digital-Teknologi.berali ke dunia modern pendidikan lebih ketat di temukan di sekitaran kita dengan cara menyempatkan diri untuk bersosialisasi satu dengan yang lain.jadi cara ini lebih spesifik membantu manusia di dalam membantu daya pikir untuk kemudian bagaimana cara untuk mengimplementasikan terhadap nilai-nilai yang telah di temukan di dalam bermsyarakat
\end{abstract}

\section{Pendahuluan}

Terkait pendahuluan saya ambil dari presepsi Kebudayaan Toraja. Dalam Kehidupan sehari hari masyarakat Toraja tidak lepas dari yang namanya kebudayaan di mana kebudayaan telah kerap kali menjadi sebuah acuan untuk memperetemukan Masyarakat degan yang lain di sebuah tempat.terkadang kebudayaan yang sering di gunakan ialah,Manasu mo raka.yang artinya Sudah madak ka,kata ini nerupakan sautu kebudayaan yang terus berangsur angsur di gunakan masyarakat Toraja sebagai bentuk sapaan.jadi ini merupakan suatu karakter yang harus di kembangkan makanya saya katakan bahwa kebudayaan bisa juga sebagai panutan utama dari pendidikan orang Toraja.Karena di dalamnya terkandung Nilai yang sangat Bermanfaat di bandingkan dengan manusia lain yang hanya sibuk main game online tidak tau apa yang harus di lakukan selanjutnya

Dalam jiwa pendidikan karakter masyarakat orang Toraja tidak hanya terlihat oleh rutinitas belajar tetapi bisa juga di lihat dari sistem perilaku karkter yang timbul dari pengaruh kebudayaan yang paling mendasar ialah kata tongkonan yang menggambarkan sebuah kerukunan di dalamnya sangat harmonis di mana tongkonanan sendiri merupaakn suatu tempat persekutuan dalam rumpun keluarga tongkonana juga merupaakn bentuk atau tempat di dalam menyelesaikan masalah.

Tujuan pendidikan karakter adalah untuk membentuk penyempurnaan diri individu secara terus menerus dan melatih kemampuan diri demi menuju kearah hidup yang lebih baik. Namun kenyataannya pendidikan karakter belum terlaksana secara maksimal, dengan kasus kasus yang 
dapat kita lihat masih banyak nya kenakalan remaja saat ini seperti, terjadinya tawuran antar pelajar bahkan dengan masyarakat, bolos sekolah, terlibat narkoba dan banyak lainnya. Oleh karena itu dibutuhkan penyuluhan atau mengadakan sosialisasi tentang pendidikan karakter bagi peserta didik agar peserta didik memiliki karakter yang baik dan dapat melekat pada dirinya"

\section{Tujuan dan Dan Manfaat}

Untuk Mengedepankan ilmu pendidikan karakter di kalangan generasi muda untuk mencapai puncak Kehidupan yang sebenarnya,

\section{Pembahasan}

\section{Kebudayaan Sebagai Wada untuk membentuk karakter di kalangan Generasi muda.}

Dalam peresempsi kebudayaan dengan pembentukan karakter tentu sangat membantu kalang muda utuk berfikir lebih kreatif di dalam mengedepankan kebudayaan sebaai wada atau tempat salah satu menempuh ilmu pendidikan.serta mempertahankan budaya tersebut

Jika kita lihat dari budaya-kultur Toraja mengenai pembentukan karakter di dalam mendapatka suatu ilmu tentu ini sangat membantu untuk kita teliti Di mana kita dapat merefleksikan mengenai karakter seperti apa yang kita dapatkan.Dalam budaya peni gggalan nenek moya orang Toraja terdapat kalimat yang pada umumnya memberikan suatu keberanian kejujuran di dalam mebantai suatu masalah daengan meniliti -nya dengan tepat.Misalkan."Mentiro Dari kata dasar tiro: melihat" "patiroi melo"k. Bagi seorang anak yang memiliki potensi kepemimpinan maka jika ia diminta: "patiroi melo" maka ia akan belajar memimpin kepada kebaikan, sebab ia akan berusaha belajar membukakan jalan untuk perbaikan (nasib bersama sekaligus kedudukannya sendiri).

Dari bagian diatas di simpulkan bawa budaya lokal yang terutama bahkan yang paling berperan penting di dalam pembentukan karakter generasi ke generasi bagaimana tidak mungin karena di dalam pembetukan karakter lewat budaya itu sendiri langsun pada prakteknya.Di Mana "Tongkonan,"atau Rumah adat Toraja Sendiri telah menjadi tempat praktek untuk pembentjkan Karakter."Terminologi Tongkonan diambil dari kata dasar"tongkon" yang berarti duduk. Dalam makna yang dipahami lebih luas adalah bahwa tongkonan itu sendiri memang merupakan lokasi, tempat (assembly atau convention hall, synode dalam bahasa Gerika) dalam rangka mendengar serta tempat untuk 'duduk' bersama membicarakan serta mengambil keputusan demi penyelesaian setiap masalah yang penting sehubungan citra tongkonan"Dari sudut pandang ini jelas bahwa sebagai wada untuk menyelesaikan masalah jadi di sini dapat berangsur angsur karakter untuk bertanggung jawab di dalam menyelesaikan masalah.

Zaman Semakin berkembang Dunia Digital Semakin Meluas tentu ini sangat mengawatirkan Jati diri kebudayaan loka tentang kepada siapa ia akan terus Berlanjut.Hal Yang Kemudia di 
lakukan di dalam merelesasikan budaya dengan dunia di gital ialah Melakukan Persahabaan Antar keduanya,Artinya Kita yang berbudaya Harus tetap memegang teguh budaya dan Berteknologi Sebagai Wada Untuk terus melanjutkan budaya itu Sendir

\section{Model pencapaian perilaku, iman karakter di tenganah-tengah Pendidikan.}

Pada umumnya Pembentukan Karakter sangat di perlukan masa kini Tetapi apa Lah daya Masia ada Karakter Anak Zama sekarang di kalangan milenial yang kurang mengimplikasikan karakter yang di peroleh di dunia pendidikan.Berbicara mengenai iman di dalam mewudukan manusia berkarakter tentunya di butuhkan doktrin dengan pembekalan praktek secara langsun cotohnya"Pendidikan iman sejatinya bukan satu-satunya diperoleh melalui pendekatan sekolah formal. Fakta adalah iman lebih dominan diperoleh (dipelajari) justru melalui budaya; dan secara konkrit lebih banyak melalui keteladanan dan interelasi individual. "Pada realitasnya bahwa dengan peryataan di atas pendidika iman lebih dominan di temukan di kebiasaan kita,budaya kultur.kebiasa yang lain itu ialah"Perilaku manusia lebih banyak berfungsi karena dibentuk oleh pengamatan dan dipengaruhi oleh proses meniru perilaku orang lain. Anak-anak melihat bagaimana orangtuanya berperilaku selanjutnya meniru lanjut perilaku tersebut"dalam perilaku yang di maksud di dini ialah perilaku positif.

Di tengah temgah pendidikan banyak ilmu yang kita dapatkan tetapi sediki yamg mampu di aplikasikan.Artinya bahwa tidak semua ilmu medidik tentang tata keimanan secara individu di dunia pendidikan satuh satunya ajaran yang mengajarkan tata keimanan lalah Mata Pelajaran Agama.tetapi pada dasarnya Ajran ini ysng bergerak di lingkup pendidikan masi kurang memberika tentang cara berkarakter yang baik serta beriman yag utuh.Mengapa tidak toh masi banyak Yang bertanya tanya Kepada siapa ka kita harus berimaan.Jadi artinya bahwa Budayala atau kebiasaan yang mampu menumbuhkan iman dan karakter di masa kini dan yang akan datang Walaupun sedemikian rupa bukan berarti pendidikan tidak perlu lagi tetapi di sarankan untuk"setiap orangtua perlu selektif dalam memilih sekolah untuk anaknya, dalam hal ini sekolah yang benar-benar menyenangi siswanya, sekolah yang memberi kemungkinan interaksi siswa dan guru yang memadai."

\section{Pembentukan Karalter di dalam Imitasi}

.Dalam Dunia Pembentukan Karakter Tentunya Ada juga yang Namanya Peniruan-Imitasi atau meniru adalah suatu proses kognisi untuk melakukan tindakan maupun aksi.yang pada itinya peniruan yang baik atau peniruan karakter yang baik,dalam dunia pemdidikan sendiri atau "Dalam konteks pendidikan akademik, salah satu subyek yang dapat memperkuat semangat menirukan teladan adalah dengan mengajarkan pelajaran 'sejarah'. Baik tokoh sejarah di panggung dunia, maupun para pahlawan dalam sejarah Negara Kesatuan Republik 
indonesia"Karakter keteladanan di sini sangan berguna karena dapat menumbuhkan rasa Nasionalisme serta keberanian untuk membela yang benara.

Selain Dari imitasi Di dalam pembentukan karakter sebagai mahkluk sosial di perlukan juga intuisi,Sebagai wadah untuk mengungkapkan jati diri manusia di dalam memelih demgan tepat sasara."Hasilnya, intuisi atau hati, kalbu atau suara hati mempunyai aspek sosial yaitu rasa komunitas, dan olehnya kita dapat mengetahui dan menginterpretasi. Pendekatan Intuisi sebagai supralogi adalah keterbukaan terhadap yang lain, apapun bentuknya, baik teks, bunyi musik atau karya seni, "

"dari dalam keluarga dan bisa tercipta jika diadakan dialog timbal balik yang saling menghargai (saya dan engkau yang setara). Intuisi yang sehat dan murni dapat menjadi kanal untuk mendidik keluarga dan masyarakat dapat dilakukan dengan berbagai cara dengan mempertimbangkan kebutuhan, usia, dan latar belakang naradidik."

\section{Pendidikan Karakter iman di tenganh era digital.}

Dalam perubahan Zaman ke zaman Pemikiran Manusi semakin cemderung berkembang Sehingga mampu menimbulkan akal-akal untuk menciptakn hal yamg baru.tetapi perlu di sadari bahwa di dalam perkembangan ilmu teknologi tentu ini sangat berdampak pada iman Kristen di dalam menjalani kehidupan sebagai manusia biasa. "Dengan adanya perkembangan Teknologi Komunikasi ini telah Membawa serta informasi informasi- Negatif yang merusak ahklak dan karakter manusia.misalnya, seks bebas, pornografi,,kekerasn perjudian,"

Dari Sudut negatif memang dunia teknologi memang meresahkan masyarakat setempat di dalam perilaku Anak temaja bahka anak-anak yang hanya melakukan rutinitas main game online tetapi dalam sundut pandang positif Perkembanan ini sangat bermanfaat.

Sudut pandang positif "Mahasiswa dengan mudah Mengakseses beberapa informasi akademik yang berkaitan denan oengajaran,penelitian,dan pemgabdian Masyaramat"

"Pendidikan sebagai sebuah proses, kini ditantang untuk dapat.menginternalisasi makna dan berbagai perubahan yang mendasar menyangkut orientasi cara pandang tersebut Untuk itu, kini amat.dibutuhkan adanya transformasi pendidikan Sekarang, pendidikan sudah harus merujuk kepada adanya konsekwensi logis dan berbagai perubahan perilaku, sikap, dan tata budaya" 


\section{Kesimpulan}

Pendidika karakter lewat kebiasan budaya sangat membantu kehidupuan manusia untuk mendapatkan tujuan hidupnya, dan iman dapat di peroleh lewat relasi kebersamaan atau lewat pendidikan yang baik,komunikasi,bersahabta dan mencitai,karakter yang baik juga mampu di aplikasikan dengan mendaya gunakan Ituisi untuk mengemukakan pendapat keberanian dalam mengambil keputusan yang benar.

\section{Daftar Pustaka}

Sanderan, R. (2020). INTUISI: Pendalaman Gagasan Hans-George Gadamer Tentang Intuisi Sebagai Supralogika. Jurnal IImiah Religiosity Entity Humanity (JIREH), 2(2), 114-125.

Sanderan, R. (2020). Heuristika dalam Pendidikan Karakter Manusia Toraja Tradisional. BIA': Jurnal Teologi dan Pendidikan Kristen Kontekstual, 3, 306-27.

Sanderan, R. (2021). EXEMPLARY, MENEMUKENALI KUNCI PENDIDIKAN IMAN BAGI ANAK DALAM KELUARGA DAN PEMBELAJARAN AGAMA DI SEKOLAH.

Sanderan, R. (2021). Disiplin Asketisme dan Harmoni Kontribusi Disiplin Diri bagi Pengembangan Pendidikan Kristen.

02 Literasi Digital dalam Perspektif Kristen; https://www.scribd.com/document/510528379/02-LiterasiDigital-dalam-Perspektif-Kristen.

Sapitri, E. Y. (2019). Pentingnya pendidikan karakter bagi peserta didik. 